\title{
REAKSI PASAR MODAL INDONESIA TERHADAP PERISTIWA VIRUS CORONA
}

\author{
${ }^{1}$ Khaulis Nia Hidayah, ${ }^{2}$ Ahmad Ainur Rozaq
}

\begin{abstract}
This research uses the event study analysis method (evet study), the research period used for 44 days with the observation period used in this study is $t-3$ (the day before the announcement) and $t+3$ (the day after the announcement) corona virus events enter Indonesia. The sample in this study focused on the CSPI during the observation period in the form of daily stock price closing data. The events examined were non-economic events, namely the Corona virus or covid 19 that affected the capital market. The population in this study are all companies listed on the IDX on the LQ45 index. The sampling technique in this study uses accidental sampling. In accidental sampling that is determination of samples based on coincidence or anyone who happens to meet with researchers can be used with samples and sampling is not determined in advance, so researchers simply collect data from sampling units that are met or already exist.
\end{abstract}

Keywords: capital market, study event, corona virus.

\begin{abstract}
ABSTRAK
Penelitian ini menggunakan metode analisis studi peristiwa (evet study), periode penelitian yang di gunakan selama 44 hari dengan Periode pengamatan yang di gunakan dalam penelitian ini adalah $\mathrm{t}-3$ ( hari sebleum pengumuman) dan $\mathrm{t}+3$ ( hari sesudah pengumuman) peristiwa virus corona masuk ke dalam indonesia. Sample pada penelitian ini tertuju pada IHSG selama periode pengamatan yaitu berupa data penutupan harga saham harian. Peristiwa yang di teliti adalah peristiwa non ekonomi yaitu adanya virus Corona atau covid 19 yang mempengaruhi pasar modal. Populasi dalam penelitian ini adalah seluruh perusahaan yang terdaftar BEI pada indeks LQ45. Tekhnik pengambilan sample pada penelitian ini menggunakan sampling aksidental. Dalam sampling aksidental yaitu penentuan sample berdasarkan kebetulan atau siapa saja yang secara kebetulan bertemu dengan peneliti dapat di gunakan dengan sample dan pengambilan sample tidak di tentukan terlebih dahulu, jadi peneliti langsung saja mengumpulkan data dari unit sampling yang di temui atau yang sudah ada.
\end{abstract}

Kata kunci: pasar modal, study event, virus corona

\section{PENDAHULUAN}

Pasar Modal adalah suatu pasar yang beroperasi secara terorganisir dimana terdapat aktifitas perdagangan surat-surat berharga seperti saham, equitas, surat pengakuan hutang, obligasi, dan surat berharga lainnya yang diterbitkan oleh pemerintah maupun perusahaan swasta dengan memanfaatkan jasa perantara, komisioner, dan underwriter. Peran pasar modal sangatlah penting bagi perekonomian suatu negara tidak terkecuali Indonesia dikarenakan memiliki dua fungsi, yaitu sarana pendanaan usaha dan sarana berinvestasi masyarakat pada pasar modal. Akan tetapi dalam beberapa bulan terakhir maraknya wabah virus diberbagai negara mengakibatkan pasar modal baik global maupun nasional tidak terkecuali Indonesia mengalami penurunan yang mengakibatkan perekonomian suatu negara tidak stabil. 
Sejak awal tahun 2020, dunia mulai di gegerkan dengan adanya virus yang mematikan serta menular dengan cepat. Virus ini di namakan virus Corona atau Covid19 yang berasal dari Wuhan, China pada akhir Desember kemarin. Virus yang di duga berasal dari hewan kelelawar ini menyerang pada sistem pernapasan manusia yang mengakibatkan gangguan pada saluran pernapasan, pneumonia akut hingga kematian. Bukan hanya berdampak pada manusia saja, virus ini juga berpengaruh dalam perputaran pasar modal Indonesia. Wabah virus Corona saat ini telah menjadi sentimen negatif bagi pasar modal khususnya di Indonesia. Dalam perdagangan sepekan kemarin, ISHG (indeks harga saham gabungan) di BEI (bursa efek Indonesia) tidak bisa melepaskan diri dari tekanan jual. ISHG akhirnya di tutup anjlok 117,548 poin dari posisi 6.076 ke 5.940. Volume perdagangan tercatat mencapai Rp.7,88 triliun dari 9,34 miliar lembar saham yang di perdagangkan (https//m.mediaindonesia.com). Ketidak stabilan ekonomi tidak hanya berdampak pada perang dagang saja, namun adanya virus Corona juga mengakibatkan perdagangan dunia terhambat bahkan banyak pabrik yang tutup untuk menimalisir dampaknya.

Pasar modal merupakan suatu instrument yang mudah di pengaruhi oleh adanya peristiwa dalam suatu negara pada perilaku keuangan baik peristiwa ekonomi maupun peristiwa non ekonomi. Dalam penelitian (Carissa Noollailie, 2018) pada reaksi harga saham dipasar modal Indonesia terhadap peristiwa teror bom periode 2002-2017 yang menyatakan dengan hipotesa menggunakan uji paired-simple t test di dapatkan bahwa tidak semua peristiwa peledakan bom di Indonesia berpengaruh terhadap pasar modal Indonesia selama periode 2002-2017. Lalu pada penelitian (Nicholas Arditya Dwianto \& Ima Kristina Yulita, 2019) pada reaksi pasar modal Indonesia terhadap peluncuran rudal Korea Utara menyatakan Abnormal return yang negatif dan signifikan tidak muncul pada saat t0 atau event date, hal ini berarti pasar modal tidak bereaksi terhadap peristiwa peluncuran rudal Korea Utara. Abnormal return yang negatif dan signifikan muncul setelah 3 hari paska peristiwa. Kemudian penelitian (Tri Suryani,2005) pada over reaksi pasar terhadap harga saham perusahaan manufaktur dibursa efek Jakarta yang menyatakan hasil pengujian hipotesis 1 menguji keberadaan reaksi berlebihan terhadap peristiwa yang terjadi selama tahun pengujian menyimpulkan bahwa terdapat indikasi reaksi berelebihan yang di tandai dengan portofolio loser menggungguli portofolio winner. Pada pengujian hipotesis 2 bahwa tidak ada perbedaan signifikan antara rata-rata abnormal return seluruh saham golongan loser maupun winner. Selanjutnya penelitian (Yulita, 2017) menyatakan bahwa dengan adanya keputusan raja Salman berinvestasi di Indonesia memberikan dampak positif dan signifikan terhadap pasar modal Indonesia.

Berdasarkan beberapa peristiwa diatas, pasar modal suatu negara khusunya Indonesia dapat dipengaruhi oleh adanya peristiwa ekonomi maupun non ekonomi. Sebelumnya, belum pernah ada penelitian mengenai reaksi pasar modal terhadap peristiwa virus Corona. Dengan uraian di atas, maka peneliti tertarik untuk menganalisis pengaruh reaksi pasar modal terhadap virus Corona. Adapun tujuan penelitian ini guna mengetahui bagaimana dampak adanya virus Corona terhadap pasar modal Indonesia. Hasil penelitian ini di harapkan dapat memberikan informasi kepada pelaku pasar modal, akademisi maupun masyarakat. 


\section{KAJIAN LITERATUR}

\section{PASAR MODAL}

(Faiza Muklis, 2016: 1) menyatakan pasar modal dalam arti sempit adalah suatu tempat dalam pengertian fisik yang teroganisasi tempat efek-efek di perdagangkan yang di sebut bursa efek. Pengertian bursa efek (stock exchange) adalah suatu sistem yang teroganisasi yang mempertemukan penjual dan pembeli efek yang di lakukan secara langsung maupun tidak langsung. Menurut (Halim, 2015:1) pasar modal adalah pasar antara pihak yang menawarkan dan yang memerlukan dana jangka panjang, seperti saham dan obligasi. Jadi bisa di simpulkan bahwa pasar modal adalah suatu tempat terkumpulnya antara pemilik modal dan pihak yang membutuhkan modal dengan memperjual belikan berbagai instrument keuangan seperti saham dan obligasi. Menurut undang-undang pasar modal No. 8 tahun 1995 tentang pasar modal mendifinisikan pasar modal sebagai kegiatan yang bersangkutan dengan penawaran umum dan perdagangan efek, perusahaan publik yang berkaitan dengan efek yang di terbitkannya serta lembaga dan profesi yang berkaitan dengan efek.

\section{SAHAM}

Saham merupakan surat bukti kepemilikan atas asset-aset perusahaan yang menerbitkan saham (Sulia, 2012: 02). Secara sederhana dapat di definisikan sebagai tanda penyertaan atau kepemilikan seseorang atau badan dalam suatu perusahaan (Faiza Muklis, 2016: 1). (Fudji, 2010: 5) menyatakan saham dapat di definisikan sebagai tanda penyertaan modal seseorang atau pihak (badan usaha) dalam suatu perusahaan atau perseroan terbatas. Dengan menyertakan modal tersebut, maka pihak tersebut memeilki klaim atas pendapatan perusahaan, klaim atas asset perubahan, dan berhak hadir dalam rapat umum pemegang saham (RUPS).

\section{VIRUS CORONA}

Virus Corona merupakan virus beramplop dengan genom RNS utas tunggal plus dan nuklekapsid berbentuk heliks simetris. Jumlah genom corona virus berkisar anatara 27-34 kilo pasangan basa, terbesar di antara virus RNA yang di ketahui. Penularan corona virus dari manusia ke manusia di perkirakan terjadi melalui kontak langsung dalam jarak dekat via tetesan kecil atu percikan (droplet) dari saluran pernapasan yang di hasilkan penderita saat bersin dan batuk. ( https://id.m.wikipedia.org )

Virus corona atau severve acute respiratory syndrome coronavirus 2 (SARS-CoV2) atau yang lebih di kenal dengan nama virus corona. Virus corona bisa menyebabkan ganguan pada sistem pernapasan, pneumonia akut, sampai kematian. Viruscorona ini termasuk virus jenis baru yang menular ke manusia dan menyerang siapa saja, baik bayi, anak-anak, orang dewasa, lansia, ibu hamil, maupun ibu menyusui. Infeksi virus ini disebut COVID-19 dan pertama kali di temukan di kota wuhan, china pada akhir desember 2019 dan telah cepat menyebar ke beberapa wilayah di china dan ke beberapa Negara, termasuk Indonesia. ( www.alodokter.com ).

\section{EVENT STUDY}

Event study suatu pengamatan mengenai pergerakan harga saham di pasar modal untuk mengetahui apakah ada abnormal return yang di peroleh pemegang saham akibat dari suatu peristiwa tertentu (suryawijaya dan setiawan, 1998). (Anastasia, 2009:1) studi peristiwa merupakan studi yang mempelajari reaksi pasar terhadap suatu peristiwa 
yang informasinya di publikasikan sebagai suatu pengumuman. Event study dapat di gunakan untuk menguji kandungan suatu informasi (information contect) dari suatu pengumuman dan dapat juga di gunakan untuk menguji hipotesis pasar efisisen (effect market hypotesis) pada bentuk setengah kuat.

\section{REAKSI PASAR}

Reaksi pasar modal di tentukan dari informasi yang terserap di pasar modal baik itu kabar buruk (bad news) atupun kabar baik (god news) (David Rofiki et al., 2018: 2). Reaksi pasar dari suatu peristiwa di proksikan dengan return tak normal (abnormal return), return tak normal yang bernilai nol menunjukkan bahwa pasar tidak bereaksi terhadap peristiwanya. Jika pasar berekasi terhadap peristiwanya , maka akan di peroleh return tak normal signifikan berbeda dengan nol. Tanda positif atau negative dari return tak normal menunjukkan arah dari reaksinya karena peristiwa kabar baik atau kabar buruk. Peristiwa kabar baik (buruk) di harapkan akan di reaksi secara positif (negatif) oleh pasar. (Nicholas dan Ima, 2019: 01).

\section{ABNORMAL RETURN}

Abnormal return menurut bahasa Indonesia adalah return yang tidak normal, maksudnya ialah kelebihan return yang sesungguhhnya terhadap return normal. Menurut Jogiyanto (2013), abnormal return merupaka selisih antara return sesungguhnya dengan return ekspetasi, return sesungguhhnya adalah return yang terjadi pada waktu ke-t yang merupakan selisih harga sekarang relatiif terhadap harga saham sebelumnya, sedangkann pada return eks[etasi merupakan return yang harus di estimasi. Menurut Tandelilin (2010), abnormal return merupakan selisih actual return dengan expectedreturn yang dapat terjadi sebelu, informasi di terbitkan atau telah terjadi kebocoran informasi setelah informasi di terbitkan.

\section{METODE PENELITIAN}

\section{Jenis Penelitian}

Pada penelitian ini menggunakan jenis penelitian studi peristiwa (study event). Study event merupakan studi yang mempelajari mengenai reaksi pasar modal terhadap suatu peristiwa. Dalam penelitian ini, Peristiwa yang di teliti adalah peristiwa non ekonomi yaitu adanya virus Corona atau covid 19 yang mempengaruhi pasar modal. Periode penelitian ini di ambil setelah presiden Joko Widodo mengemumkan virus covid 19 telah masuk ke Indonesia sampai pada bulan april . Jenis data yang di gunakan pada penelitian ini menggunakan pendekatan kuantitatif dimana menggunakan data berupa angka sebagai alat menganalisis keterangan mengenai apa yang ingin di ketahui. Sedangkan sumber data yang di peroleh dari data sekunder yaitu data yang di peroleh peneliti dari sumber yang telah ada.

\section{Sampling Method}

Teknik pengambilan sampel pada penelitian ini menggunakan sampling aksidental. Dalam sampling aksidental yaitu penentuan sample berdasarkan kebetulan atau siapa saja yang secara kebetulan bertemu dengan peneliti dapat di gunakan dengan sample dan pengambilan sample tidak di tentukan terlebih dahulu, jadi peneliti langsung saja mengumpulkan data dari unit sampling yang di temui atau yang sudah ada. 


\section{Populasi dan Sample}

Populasi dalam penelitian ini adalah seluruh perusahaan yang terdaftar BEI pada indeks LQ45 selama periode pengamatan pada bulan Februari 2020 sampai mei 2020 terdapat 45 emiten sebagai berikut:

\section{Table 1. Data perusahaan yang terdaftar di indek LQ45}

\begin{tabular}{|c|c|c|c|}
\hline 1 & ACES & Ace Hardware Indonesia Tbk. & $\begin{array}{l}\text { Trade, Service \& } \\
\text { Investment }\end{array}$ \\
\hline 2 & ADRO & Adaro Energy Tbk. & Mining \\
\hline 3 & AKRA & AKR Corporindo Tbk. & $\begin{array}{l}\text { Trade, Service \& } \\
\text { Investment }\end{array}$ \\
\hline 4 & ANTM & Aneka Tambang (Persero) Tbk & Mining \\
\hline 5 & ASII & Astra International Tbk. & Misc Industry \\
\hline 6 & BBCA & Bank Central Asia Tbk. & Finance \\
\hline 7 & $\mathrm{BBNI}$ & Bank Negara Indonesia (Persero) Tbk. & Finance \\
\hline 8 & BBRI & Bank Rakyat Indonesia (Persero) Tbk & Finance \\
\hline 9 & BBTN & Bank Tabungan Negara (Persero) Tbk. & Finance \\
\hline 10 & BMRI & Bank Mandiri (Persero) Tbk. & Finance \\
\hline 11 & BRPT & Barito Pacific Tbk. & Chemical Industry \\
\hline 12 & BSDE & Bumi Serpong Damai. & Property \& Construction \\
\hline 13 & BTPS & $\begin{array}{l}\text { Bank Tabungan Pensiunan National } \\
\text { Syariah Tbk }\end{array}$ & Finance \\
\hline 14 & CPIN & Charoen Pokphand Indonesia Tbk. & Chemical Industry \\
\hline 15 & CTRA & Ciputra Development Tbk. & Property \& Construction \\
\hline 16 & ERAA & Erajaya Swasembada Tbk. & $\begin{array}{l}\text { Trade, Service \& } \\
\text { Investment }\end{array}$ \\
\hline 17 & EXCL & XL Axiata Tbk. & $\begin{array}{l}\text { Infrastructure \& } \\
\text { Transportation }\end{array}$ \\
\hline 18 & GGRM & Gudang Garam Tbk. & Consumer Goods \\
\hline 19 & HMSP & H.M. Sampoerna Tbk. & Consumer Goods \\
\hline
\end{tabular}




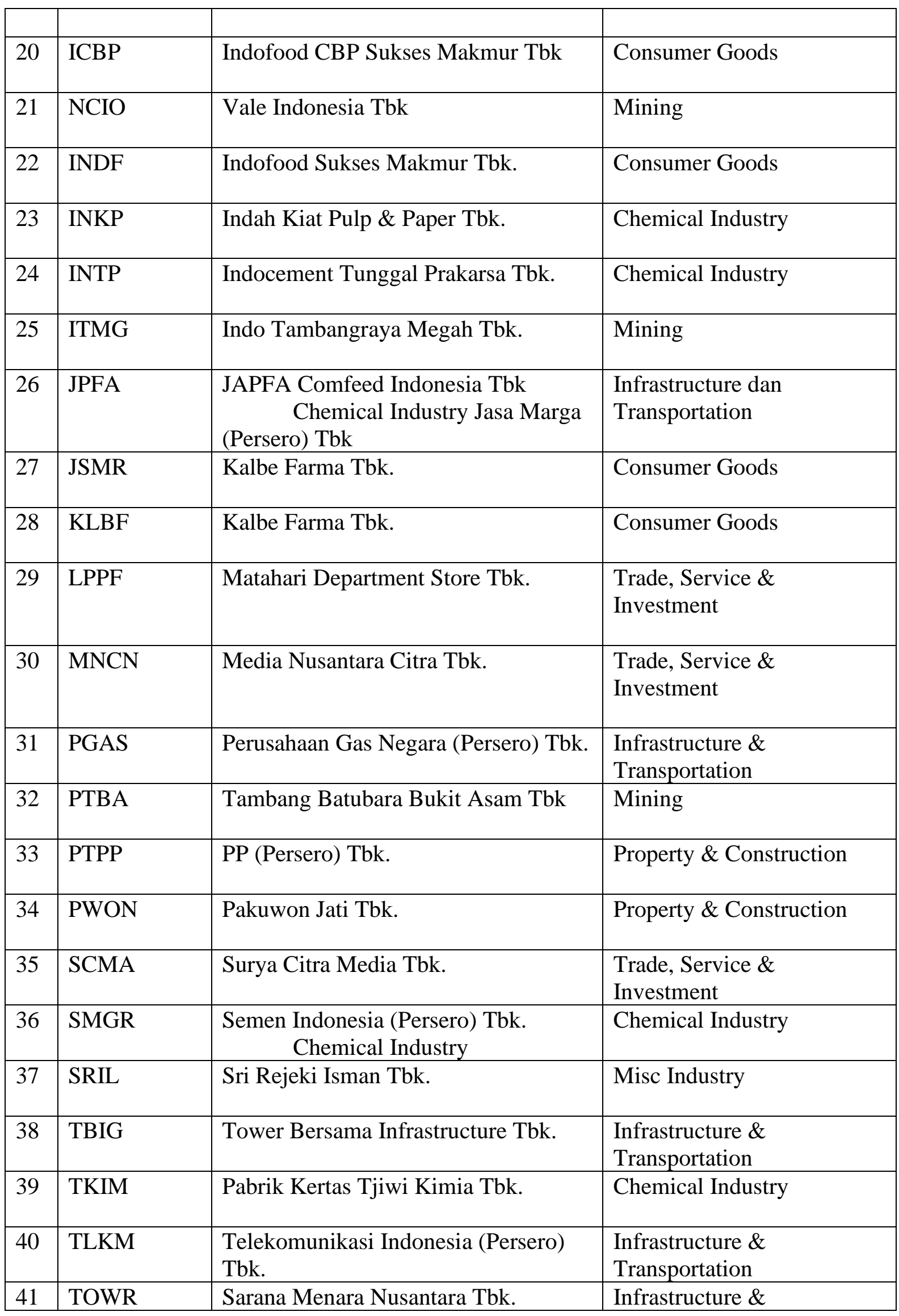




\begin{tabular}{|l|l|l|l|}
\hline & & & Transportation \\
\hline 42 & UNTR & United Tractors Tbk. & $\begin{array}{l}\text { Trade, Service \& } \\
\text { Investment }\end{array}$ \\
\hline 43 & UNVR & $\begin{array}{r}\text { Unilever Indonesia Tbk. } \\
\text { Consumer Goods }\end{array}$ & Consumer Goods \\
\hline 44 & WIKA & Wijaya Karya (Persero) Tbk. & Property \& Construction \\
\hline 45 & WSKT & Waskita Karya (Persero) Tbk. & Property \& Construction \\
\hline
\end{tabular}

Periode pengamatan yang di gunakan dalam penelitian ini adalah t-3 ( hari sebleum pengumuman) dan $\mathrm{t}+3$ ( hari sesudah pengumuman) peristiwa virus corona masuk ke dalam Indonesia. Sample pada penelitian ini tertuju pada IHSG selama periode pengamatan yaitu berupa data penutupan harga saham harian yang di akses melalui (https://www.duniainvestasi.com ) saat perdagangan saham pada periode 25 februari-30 april 2020. Dengan data sebagai berikut:

2. Table 2. Data IHSG harian close trading di pasar modal Indonesia.

\begin{tabular}{|l|l|}
\hline $25-02-2020$ & $5,452.7040$ \\
\hline $26-02-2020$ & $5,535.6940$ \\
\hline $27-02-2020$ & $5,688.9210$ \\
\hline $02-03-2020$ & $5,361.2460$ \\
\hline $03-03-2020$ & $5,518.6280$ \\
\hline $04-03-2020$ & $5,650.1360$ \\
\hline $05-03-2020$ & $5,638.1300$ \\
\hline $06-03-2020$ & $5,498.5400$ \\
\hline $09-03-2020$ & $5,136.8090$ \\
\hline $10-03-2020$ & $5,220.8260$ \\
\hline $11-03-2020$ & $5,154.1050$ \\
\hline $12-03-2020$ & $4,895.7480$ \\
\hline $13-03-2020$ & $4,907.5710$ \\
\hline $16-03-2020$ & $4,690.6570$ \\
\hline $17-03-2020$ & $4,456.7490$ \\
\hline $18-03-2020$ & $4,330.6740$ \\
\hline
\end{tabular}




\begin{tabular}{|l|l|}
\hline $19-03-2020$ & $4,105.4220$ \\
\hline $20-03-2020$ & $4,194.9440$ \\
\hline $23-03-2020$ & $3,989.5170$ \\
\hline $24-03-2020$ & $3,937.6320$ \\
\hline $26-03-2020$ & $4,338.9040$ \\
\hline $27-03-2020$ & $4,545.5710$ \\
\hline $30-03-2020$ & $4,414.5000$ \\
\hline $31-03-2020$ & $4,538.9300$ \\
\hline $01-04-2020$ & $4,649.0790$ \\
\hline $02-04-2020$ & $4,531.6850$ \\
\hline $03-04-2020$ & $4,623.4290$ \\
\hline $06-04-2020$ & $4,811.8270$ \\
\hline $07-04-2020$ & $4,778.6390$ \\
\hline $08-04-2020$ & $4,626.6950$ \\
\hline $09-04-2020$ & $4,466.0370$ \\
\hline $13-04-2020$ & $4,623.8940$ \\
\hline $14-04-2020$ & $4,706.4910$ \\
\hline $15-04-2020$ & $4,625.9050$ \\
\hline $16-04-2020$ & $4,480.6070$ \\
\hline $17-04-2020$ & $4,634.8210$ \\
\hline $20-04-2020$ & $4,575.9050$ \\
\hline $21-04-2020$ & $4,501.9190$ \\
\hline $22-04-2020$ & $4,567.5620$ \\
\hline $23-04-2020$ & $4,593.5540$ \\
\hline $24-04-2020$ & $4,496.0640$ \\
\hline $27-04-2020$ & $4,513.1410$ \\
\hline $28-04-2020$ & $4,529.5540$ \\
\hline $29-04-2020$ & $4,567.3230$ \\
\hline & \\
\hline
\end{tabular}




\begin{tabular}{|l|l|}
\hline $30-04-2020$ & $4,716.4030$ \\
\hline
\end{tabular}

\section{Alat Analisis dan Penggunaan}

Alat yang di gunakan untuk menganalisis data adalah menggunakan program aplikasi SPSS versi 25 dimana menggunakan data statistika untuk mengetahui ada dan tidaknya abnormal return terhadap pasar modal.

\section{HASIL DAN PEMBAHASAN}

\section{Gambar 1. Grafik rata-rata abnormal return saham secara harian selama} periode peristiwa.

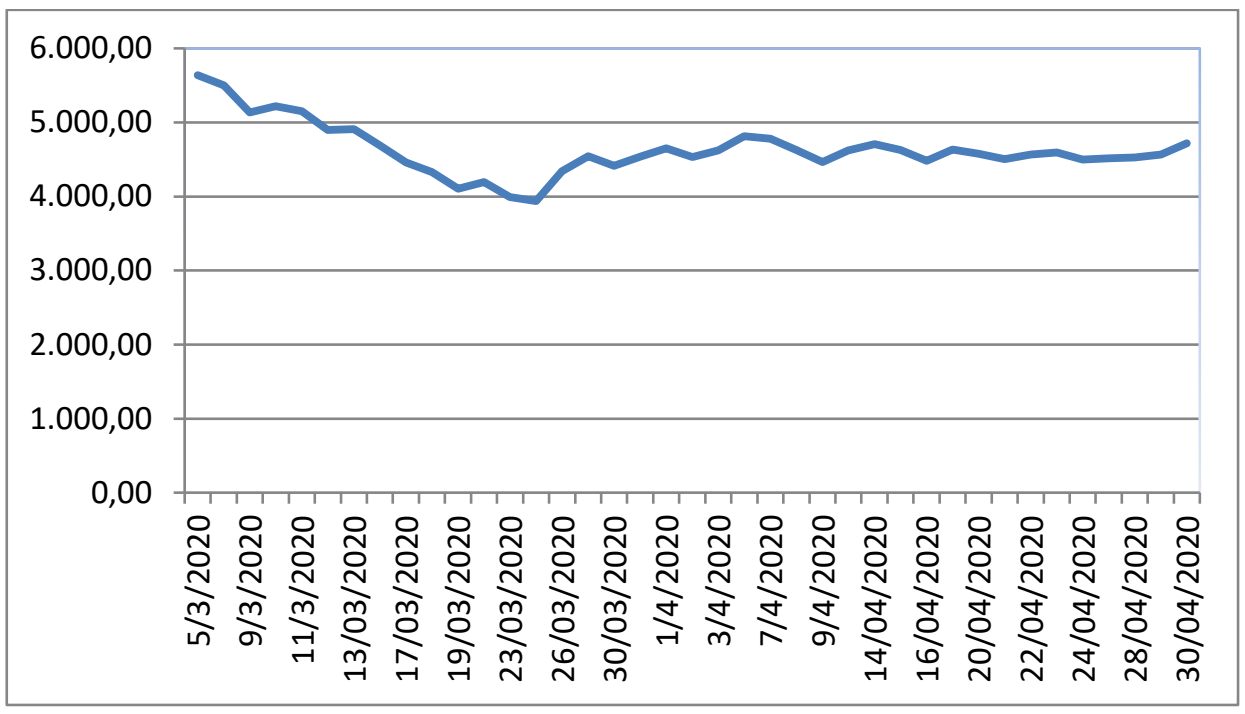

Melihat data yang di tampilkan pada grafik tersebut menunjukkan penurunan perdagangan saham saat close trading pada bulan Februari tanggal 25 sebelum pengumuman adanya virus Corona masuk ke Indonesia menandakan tanda merah sebagia adanya reaksi pasar modal terhadap virus corona, virus Corona memberikan dampak yang cukup signifkan terhadap pasar modal. Begitupun sesudah pengumuman peristiwa adanya virus corona masuk ke Indonesia yang di paparkan oleh presiden joko widodo pada tanggal 02 maret 2020, dari data yang ada IHSG menurun saat trading close adanya change 91.4580 .

Dari semua data yang tergabung pada IHSG banyak menandakan penuruanan saat close tranding harian di bursa efek, ini menandakan bahwa pasar bereaksi adanya virus corona yang masuk ke Indonesia, bahkan bisa di bilang black swan dalam pasar modal Indonesia. Banyak perusahaan yang menanam saham di bursa efek indonesia terkena dampak dari virus corona ini. Sehingga Indeks Harga Saham Gabungan (IHSG) yang akhirnya terjun bebas, semua beada di luar prediksi dan bukan hal yang mudah untuk di kendalikan. 
Table 3. hasil uji one sample T-test terhadap abnormal return selama periode penelitian

\section{One-Sample Statistics}

\begin{tabular}{ll|l|l|ll} 
& N & Mean & $\begin{array}{l}\text { Std. } \\
\text { Deviation }\end{array}$ & $\begin{array}{l}\text { Std. Error } \\
\text { Mean }\end{array}$ \\
\hline sebelum & 3 & 5559.11 & 119.836 & 69.187 & \\
\hline sesudah & 41 & 4695.66 & 412.589 & 64.436 \\
\hline
\end{tabular}

\section{One-Sample Test}

Test Value $=0$

\begin{tabular}{|c|c|c|c|c|c|c|}
\hline & $\mathrm{t}$ & $\mathrm{df}$ & $\begin{array}{l}\text { Sig. } \\
\text { tailed })\end{array}$ & $\begin{array}{l}\text { Mean } \\
\text { Difference }\end{array}$ & $\begin{array}{l}95 \% \text { Confiden } \\
\text { the Difference } \\
\text { Lower }\end{array}$ & $\begin{array}{l}\text { ice Interval of } \\
\text { Upper }\end{array}$ \\
\hline sebelum & 80.348 & 2 & .000 & 5559.106 & 5261.42 & 5856.80 \\
\hline sesudah & 72.874 & 40 & .000 & 4695.656 & 4565.43 & 4825.88 \\
\hline
\end{tabular}

Sumber: data sekunder di olah (2020)

Table 4. hasil uji paired sample T-test average abnormal return selama penutupan trading di BEI selama perisiwa.

Paired Samples Statistics

\begin{tabular}{|c|c|c|c|c|c|}
\hline & & Mean & $\mathrm{N}$ & $\begin{array}{l}\text { Std. } \\
\text { Deviation }\end{array}$ & $\begin{array}{ll}\text { Std. } & \text { Error } \\
\text { Mean } & \\
\end{array}$ \\
\hline \multirow[t]{2}{*}{ Pair 1} & sebelum & 5559.11 & 3 & 119.836 & 69.187 \\
\hline & sesudah & 5510.00 & 3 & 144.638 & 83.507 \\
\hline
\end{tabular}

\section{Paired Samples Test}

\begin{tabular}{|c|c|c|c|c|c|c|c|c|c|}
\hline & & \multicolumn{5}{|c|}{ Paired Differences } & \multirow[b]{2}{*}{$\mathrm{t}$} & \multirow[b]{2}{*}{ df } & \multirow[b]{2}{*}{$\begin{array}{l}\text { Sig. } \\
\text { tailed) }\end{array}$} \\
\hline & & $\begin{array}{l}\text { Mea } \\
n\end{array}$ & $\begin{array}{l}\text { Std. } \\
\text { Deviati } \\
\text { on }\end{array}$ & $\begin{array}{l}\text { Std. } \\
\text { Error } \\
\text { Mean }\end{array}$ & $\begin{array}{l}95 \% \\
\text { Confid } \\
\text { Interva } \\
\text { Differe } \\
\text { Lower }\end{array}$ & $\begin{array}{l}\text { ence } \\
1 \text { of the } \\
\text { nce } \\
\text { Upper }\end{array}$ & & & \\
\hline Pair 1 & $\begin{array}{l}\text { sebe } \\
\text { lum } \\
- \\
\text { sesu } \\
\text { dah }\end{array}$ & $\begin{array}{l}49.10 \\
3\end{array}$ & 38.254 & 22.086 & $\begin{array}{l}- \\
45.92 \\
6\end{array}$ & $\begin{array}{l}144.1 \\
32\end{array}$ & 2.223 & 2 & .156 \\
\hline
\end{tabular}

Sumber: Data sekunder di olah (2020) 
Dari berbagai data yang dperoleh, kita menemukan ada 10 perusahaan yang sangat terdampak virus Corona pada saham-saham sektor konsumen dan perdagangan yang mengalami pemerosotan yang mendalam.

1. PT. Japfa Comfeed Indonesia (JPFA) Pada saham JPFA merosot 51 persen dari harga Rp.1.700 per lembar saham menjadi Rp. 835 per lembar saham.

2. PT HM Sampoerna Tbk (HMSP) juga ikut anjlok 40 persen dari harga Rp 2.200 menjadi Rp 1.300 per lembar saham

3. PT Matahari Departemen Store Tbk (LPPF) paling terdampak dari harga Rp 4.300 menjadi Rp 1.500 per lembar saham atau merosot 63 persen.

4. PT Indofood CBS Sukses Makmur (ICBP) jatuh dari Rp 11.500 ke Rp 8.900. (Minus 20 persen).

5. PT HM Sampoerna Tbk (HMSP) jatuh dari Rp 2.200 ke Rp 1.300. (Minus 40 persen).

6. PT Gudang Garam Tbk (GGRM) jatuh dari Rp 55.000 ke Rp 39.000. (Minus 29 oersen ).

7. PT Japfa Comfeed Indonesia Tbk (JPFA) jatuh dari Rp 1.700 ke Rp 835. (Minus 51 persen).

8. PT Charoen Pokphand Indonesia Tbk (CPIN) jatuh dari Rp 7.300 ke Rp 4.210. (Minus 42 persen).

9. PT Astra Internasional Tbk (ASII) jatuh dari Rp 7.100 ke Rp 3.700. (Minus 47 persen).

10. PT Matahari Departement Store (LPPF) jatuh dari harga Rp 4.300 ke Rp 1.550. (Minus 63 persen)

Dari saham-saham di atas kami mengambil empat perusahaan yang akan di analisis, apakah ada pengaruh yang signifikan terhadap perusahaan-perusahaan tersebut.

\section{JAPFA COMFEED Indonesia Tbk (JPFA)}

\begin{tabular}{|l|l|}
\hline JPFA \\
\hline Tanggal & Close \\
\hline $25 / 02 / 2020$ & 1.495 \\
\hline $26 / 02 / 2020$ & 1.455 \\
\hline $27 / 02 / 2020$ & 1.425 \\
\hline $02 / 03 / 2020$ & 1.460 \\
\hline $03 / 03 / 2020$ & 1.495 \\
\hline $04 / 03 / 2020$ & 1.520 \\
\hline $05 / 03 / 2020$ & 1.520 \\
\hline
\end{tabular}

Sumber: duniainvesting.com

Dari table dia atas adanya data historis harian close trading pada saham JPFA yang di perdagangkan di pasar modal Indonesia. Tanda merah merupakan event date saat pengumuman virus corona masuk ke Indonesia. Berkut data analisisnya : 


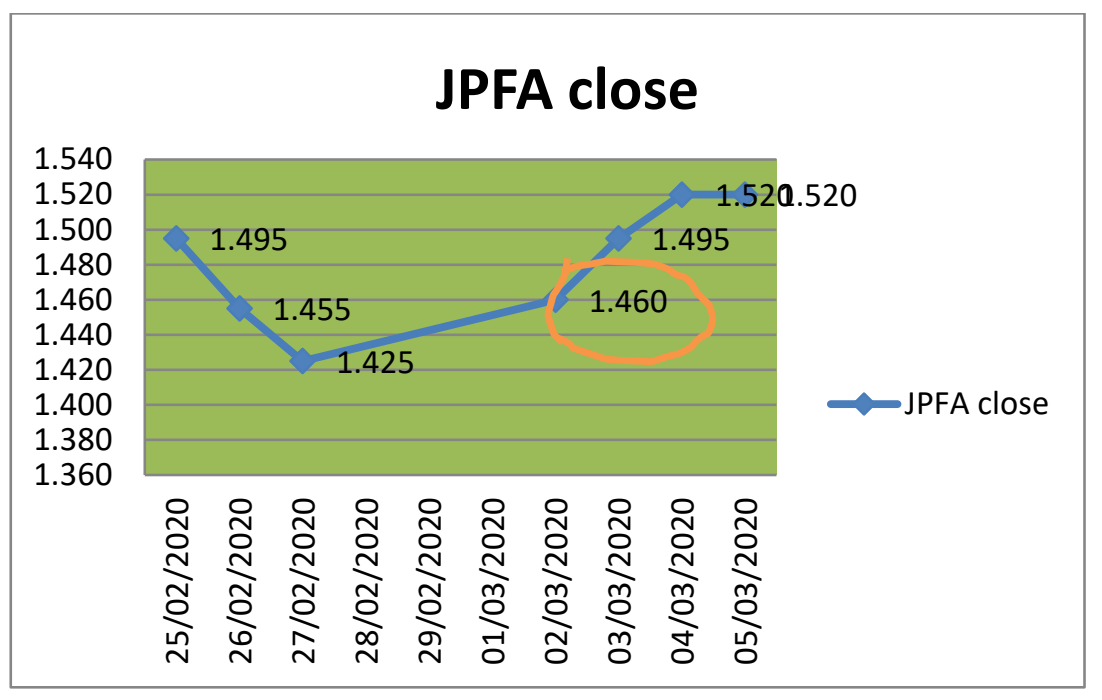

Pada gambar grafik di atas pada lingkaran merah merupakan t0 (event date), terjadi penurunan yang cukup signifikan terhadap $t-1=1.425$ peristiwa di umumkan dan pada $t+1=1.495$ peristiwa di umumkan, pasar cukup bereaksi saat sebelum pengumuman.

\section{HM SAMPOERNA TbK (HMSP)}

\begin{tabular}{|l|l|}
\hline \multicolumn{2}{|l|}{ HMSP } \\
\hline Tanggal & close \\
\hline $25 / 02 / 2020$ & 1.860 \\
\hline $26 / 02 / 2020$ & 1.785 \\
\hline $27 / 02 / 2020$ & 1.730 \\
\hline $02 / 03 / 2020$ & 1.675 \\
\hline $03 / 03 / 2020$ & 1.750 \\
\hline $04 / 03 / 2020$ & 1.785 \\
\hline $05 / 03 / 2020$ & 1.785 \\
\hline
\end{tabular}

Dari table dia atas adanya data historis harian close trading pada saham HMSP yang di perdagangkan di pasar modal Indonesia. Tanda merah merupakan event date saat pengumuman virus corona masuk ke Indonesia. Berkut data analisisnya : 


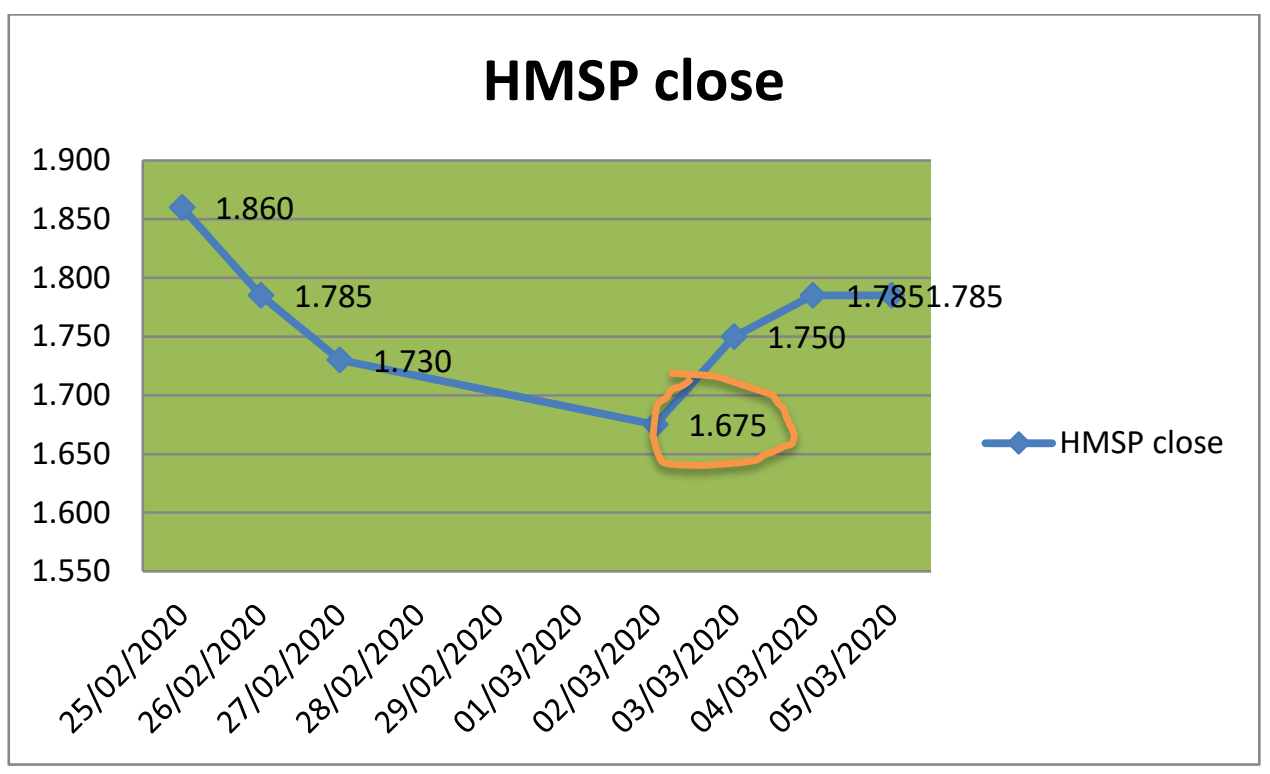

Dari grafik di atas menunjukkan penurunan saat event date pengumuman peristiwa, pada saat $\mathrm{t}-3$ harga clsoinng trading masih normal sampai pada $\mathrm{t} 3$ pengumuamn peristiwa cukup menurun ke harga 1.785 .

\section{GUDANG GARAM TBK (GGRM)}

\begin{tabular}{|l|l|}
\hline \multicolumn{2}{|l|}{ GGRM } \\
\hline tanggal & close \\
\hline $25 / 02 / 2020$ & 55.200 \\
\hline $26 / 02 / 2020$ & 55.000 \\
\hline $27 / 02 / 2020$ & 53.000 \\
\hline $02 / 03 / 2020$ & 49.500 \\
\hline $03 / 03 / 2020$ & 50.775 \\
\hline $04 / 03 / 2020$ & 51.775 \\
\hline $05 / 03 / 2020$ & 50.950 \\
\hline
\end{tabular}

Dari table dia atas adanya data historis harian close trading pada saham GGRM yang di perdagangkan di pasar modal Indonesia. Tanda merah merupakan event date saat pengumuman virus corona masuk ke Indonesia. Berkut data analisisnya : 


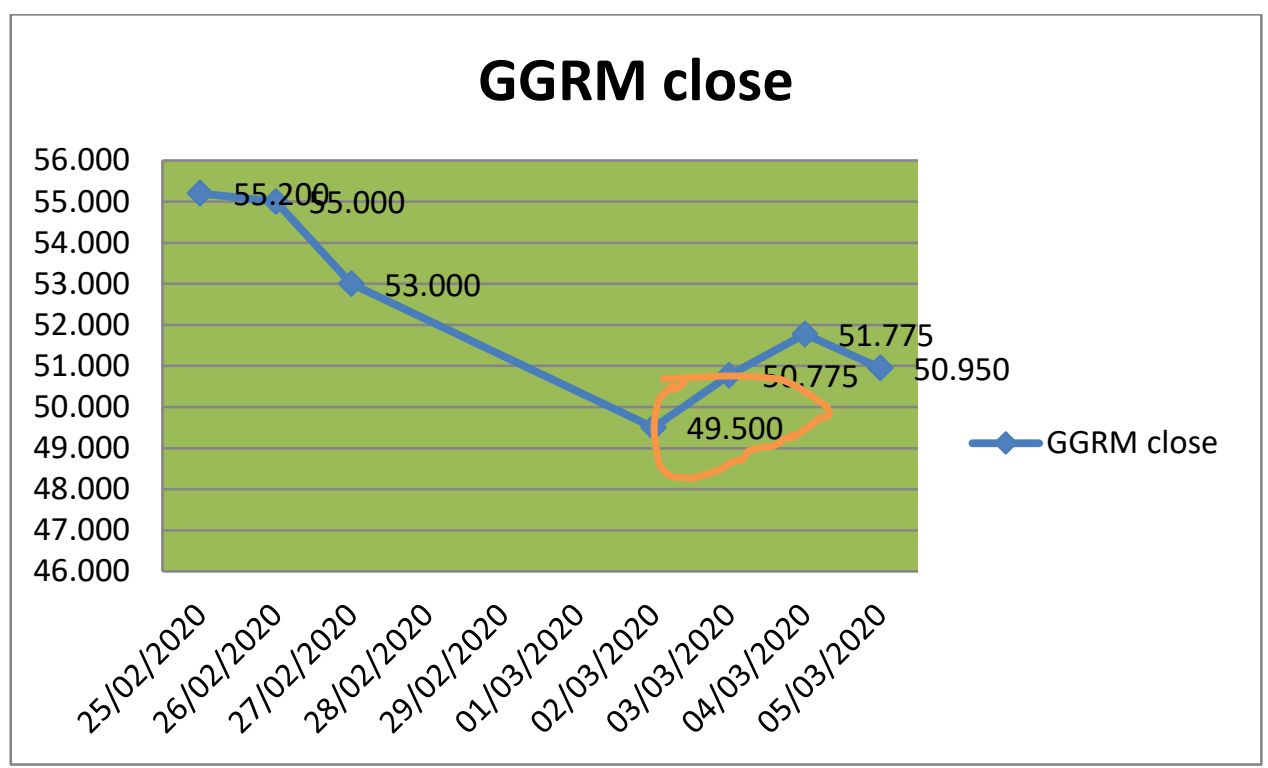

Hasil dari grafik di atas meggambarkan penurunan yang sangat signifikan teerhadap harga close trading pada saham GGRM, saat event date sangat terlihat terdapat penurunan yang sangat dalam. Dari harga $t-3=55.200$ sampai $t+3=50.950$

4. Matahari department store Tbk (LPFF)

\begin{tabular}{|l|l|}
\hline LPFF \\
\hline tanggal & close \\
\hline $25 / 02 / 2020$ & 3.210 \\
\hline $26 / 02 / 2020$ & 3.150 \\
\hline $27 / 02 / 2020$ & 3.080 \\
\hline $02 / 03 / 2020$ & 3.090 \\
\hline $03 / 03 / 2020$ & 3.190 \\
\hline $04 / 03 / 2020$ & 3.210 \\
\hline $05 / 03 / 2020$ & 2.980 \\
\hline
\end{tabular}

Dari table dia atas adanya data historis harian close trading pada saham LPFF yang di perdagangkan di pasar modal Indonesia. Tanda merah merupakan event date saat pengumuman virus corona masuk ke Indonesia. Berkut data analisisnya : 


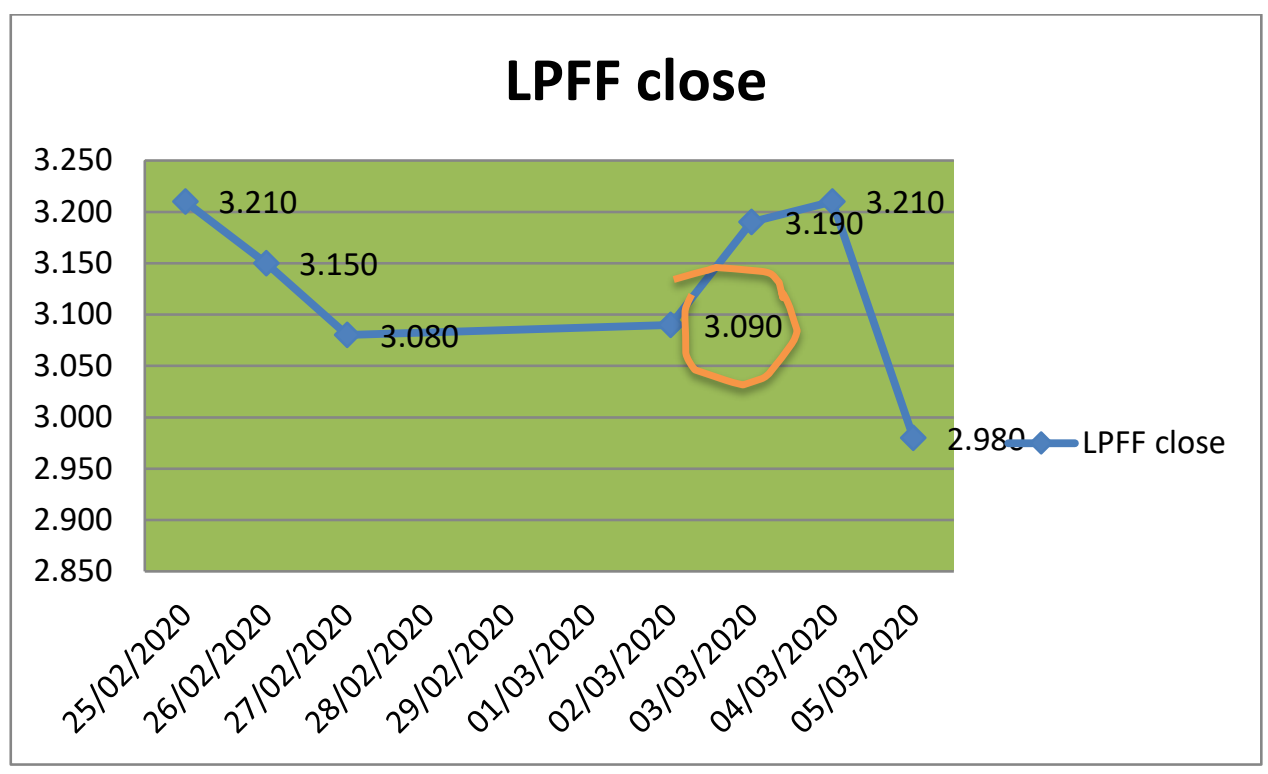

Hasil dari grafik di atas menggambarkan penurunan yang cukup signifikan terhadap harga closing trading saham LPFF, pada $\mathrm{t}-3=3.210$, $\mathrm{t} 0=3.090$ sempat kembali normal pada $t+2=3.210$ lalu penurun secara sgnifikan pada $t+3=2.980$.

\section{SIMPULAN}

1. Adanya virus Corona atau Covid-19 berasal dari Wuhan, China yang masuk ke Indonesia pada 02 Maret 2020 memberikan dampak yang cukup signifkan terhadap pasar modal indonesia. Berdasarkan Indeks Harga Saham Gabungan (ISHG) terjadi penurunan trading close dari yang biasanya berada diposisi 60005000an kini menurun rata-rata dikisaran 4000an terhitung sejak awal bulan Maret 2020 sampai bulan Mei 2020.

2. Berdasarkan data yang diperoleh, ada 10 perusahaan yang sangat terdampak virus Corona sehinga mengalami pemerosotan yang mendalam. Diantaranya PT. Japfa Comfeed Indonesia (JPFA), PT HM Sampoerna Tbk (HMSP), PT Matahari Departemen Store Tbk (LPPF), PT Indofood CBS Sukses Makmur (ICBP), PT HM Sampoerna Tbk (HMSP), PT Gudang Garam Tbk (GGRM), PT Japfa Comfeed Indonesia Tbk (JPFA), PT Charoen Pokphand Indonesia Tbk (CPIN), PT Astra Internasional Tbk (ASII) dan PT Matahari Departement Store (LPPF).

3. Bedasarkan hasil uji statistik terhadap antara periode sebelum pengumuman dan saat pengumuman adanya Corona masuk ke Indonesia, menunjukkan bahwa terdapat perbedaan berupa penurunan close trading yang cukup signifikan. 


\section{DAFTAR PUSTAKA}

Ananta, Diki. (2020). Koronavirus. https://id.m.wikipedia.org/wiki/Koronavirus id.m.wikipedia.org (19 Maret 2020).

Cindy, Carissa F. dan Soewarno, NoorLailie. (2017). Reaksi Harga Saham Di Pasar Modal Indonesia Terhadap Peristiwa Bom Periode 2002-2017. Jurnal Akuntansi Universitas Jember. Vol. 15 (2) 21-22.

Dwianto, Nicholas Arditya dan Yunita, Ima Kristina. (2019). Reaksi Pasar Modal Indonesia Terhadap Peluncuran Rudal Korea Utara. EXERO Journal of Research in Businnes and Economics Vol. 2 (1) 26.

Mar'ati, Fudji Sri. (2010). Mengenal Pasar Modal (Instrumen Pokok Dan Proses Go Public). Among Makarti vol. 3 (5) 79-80.

Muklis, Faiza. (2016). Perkembangan Dan Tantangan Pasar Modal Indonesia. Al Masraf (Jurnal Perkembangan Keuangan Dan Perbankan. Vol. 1 (1) 66.

Nadia, Sosro. (2020). Japfa Comfeed Indonesia Tbk (JPFA). https://m.id.investing.com/equities/japfa-comfeed-historical-data (1 Mei 2020).

Pane, Merry Dame Cristy. (2020). Virus Corona. https://www. Alodokter.com?viruscorona (22 Maret 2020).

Rofiki, David, Topowijono dan Nurlaily. Ferlina.(2018). Reaksi Pasar Modal Indonesia Akibat Peristiwa Pemilihan Gubernur DKI Jakarta Putaran II 2017. Jurnal Administrasi Bisnis Vol. 62 (2) 188.

Sulia. (2017). Analisis Faktor-Faktor Yang Mempengaruhi Harga Saham Pada Perusahaan LQ45 Yang Terdaftar Di Bursa Efek Indonesia. Jurnal Ekonomi Mikroskil Vol. 7 (2) 1.

Suryani, Tri. (2016). Over Reaksi Pasar Terhadap Harga Saham Perusahaan Manufaktur Di Bursa Efek Jakarta. eJournal Administrasi Bisnis Vol. 2 (2) 4347.

Telaumbauna, Binsar I. K., dan Sumiyana. (2008). Event Study: Pengumuman Laba Terhadap Reaksi Pasar Modal (Study Empiris Bursa Efek Indonesia 20042006). Jurnal Manajemen Teori dan Terapan Vol. 1 (3) 25-27. 